\title{
Grow-out of spiny lobster Panulirus sp. with high stocking density in controlled tanks
}

\section{Pembesaran lobster laut Panulirus sp. dengan kepadatan tinggi dalam bak terkontrol}

\author{
Rio Yusufi Subhan ${ }^{1 *}$, Eddy Supriyono ${ }^{2}$, Widanarni² $^{2}$, Daniel Djokosetiyanto ${ }^{2}$ \\ ${ }^{1}$ Postgraduate student of Aquaculture Science, Bogor Agricultural University, West Java 16680 \\ ${ }^{2}$ Department of Aquaculture, Faculty of Fisheries and Marine Science, Bogor Agricultural University \\ West Java, Indonesia 16680 \\ "E-mail: rioysubhan@gmail.com
}

(Received January 11, 2018; Accepted March 23, 2018)

\begin{abstract}
The aim of this research was to determine optimum stocking density for growing-out of spiny lobster Panulirus sp. in controlled tanks that conducted for 30 days. The experimental spiny lobsters have the initial average weight of $130.39 \pm 0.32 \mathrm{~g}$ and initial average total length of $140.70 \pm 0.06 \mathrm{~mm}$. This study used completely randomized design with three different stocking densities $\left(\mathrm{KT}_{10}: 10 \mathrm{ind} / \mathrm{m}^{3} ; \mathrm{KT}_{18}: 18 \mathrm{ind} / \mathrm{m}^{3}\right.$; and $\left.\mathrm{KT}^{26}: 26 \mathrm{ind} / \mathrm{m}_{3}\right)$ and two replications. The parameters observed in this study included water quality (temperature, $\mathrm{pH}$, salinity, dissolved oxygen, and total ammonia nitrogen), physiological responses (total haemocyte count, haemolymph glucose, and frequency of molt), and production performances, such as growth, specific growth rate, feed conversion ratio, and survival rate. The results showed that the spiny lobster could be reared in high stocking density in controlled tanks. Water quality during the study in each treatment was; temperature $26.56-28.65^{\circ} \mathrm{C}$, salinity $29.7-33.6 \mathrm{~g} / \mathrm{L}$, pH 7.5-8.5, dissolved oxygen $6.15-6.58 \mathrm{mg} / \mathrm{L}$, and total ammonia nitrogen $0.11-0.34 \mathrm{mg} / \mathrm{L}$. The best stocking densities for spiny lobster was $18 \mathrm{ind} / \mathrm{m}^{3}$ (KT18) with $2.5-3.5 \times 10^{6} \mathrm{cell} / \mathrm{s} / \mathrm{mL}$ total haemocyte counts, 24.6-28.3 $\mathrm{mg} / \mathrm{dL}$ haemolymph glucose, and $38.37 \pm 3.20 \%$ frequency of molt. The final average body weight and length were $145.06 \pm 0.42 \mathrm{~g}$ and $142.77 \pm 0.19 \mathrm{~mm}$, respectively. The survival rate reached $86.11 \pm 3.92 \%$ with a specific growth rate $0.35 \pm 0.01 \% /$ day, and feed conversion ratio $7.87 \pm 0.31$.
\end{abstract}

Keywords: high stocking density, Panulirus sp., physiological responses, productivity.

\begin{abstract}
ABSTRAK
Tujuan dari penelitian ini adalah untuk menentukan kepadatan terbaik dalam pembesaran lobster laut Panulirus sp. yang dipelihara dalam bak terkontrol selama 30 hari. Lobster laut yang digunakan pada awal penelitian memiliki bobot 130,39 $\pm 0,32 \mathrm{~g}$ dan panjang total 140,70 $\pm 0,06 \mathrm{~mm}$. Penelitian dilakukan menggunakan rancangan acak lengkap dengan tiga perlakuan kepadatan berbeda, yaitu: $10 \mathrm{ekor} / \mathrm{m} 3\left(\mathrm{KT}_{10}\right), 18 \mathrm{ekor} / \mathrm{m}^{3}\left(\mathrm{KT}_{18}\right)$, dan $26 \mathrm{ekor} / \mathrm{m}_{3}$ $\left(\mathrm{KT}_{26}\right)$ dan dua ulangan. Parameter uji yang diamati dalam penelitian ini meliputi kualitas air (suhu, salinitas, $\mathrm{pH}$, DO, dan TAN), respons fisiologis (total hemosit/THC, glukosa hemolim, dan frekuensi pergantian kulit), dan kinerja produksi meliputi pertumbuhan, laju pertumbuhan spesifik, rasio konversi pakan, dan tingkat kelangsungan hidup. Hasil penelitian menunjukkan bahwa lobster laut dapat dibesarkan dengan kepadatan tinggi dalam bak terkontrol. Pengukuran nilai kualitas air pada setiap perlakuan selama pemeliharaan adalah suhu berkisar 26,5628,65oC, salinitas 29,7-33,6 g/L, pH 7,5-8,5, DO antara 6,15-6,58 mg/L dan TAN antara 0,11-034 mg/L. Perlakuan terbaik selama penelitian adalah dengan kepadatan $18 \mathrm{ekor} / \mathrm{m}^{3}(\mathrm{KT} 18)$ dengan nilai THC berkisar antara $2,5-3,5 \times 10^{6} \mathrm{sel} / \mathrm{mL}$, glukosa hemolim $24,6-28,3 \mathrm{mg} / \mathrm{dL}$, dan frekuensi pergantian kulit 38,37 $\pm 3,20 \%$. Bobot dan panjang lobster akhir rata-rata pada perlakuan tersebut masing-masing mencapai 145,06 $\pm 0,42 \mathrm{~g}$, dan 142,77 \pm $0,19 \mathrm{~mm}$. Tingkat kelangsungan hidup mencapai $86,11 \pm 3,92 \%$ dengan laju pertumbuhan spesifik $0,35 \pm 0,01 \% /$ hari dan rasio konversi pakan selama penelitian adalah $7,87 \pm 0,31$.
\end{abstract}

Kata kunci: padat pemeliharaan, Panulirus sp., produktivitas, respons fisiologis. 


\section{INTRODUCTION}

Spiny lobster (Panulirus sp.) is a high economic value marine water commodity with a market price around IDR 250,000-350,000/kg, while for export market around IDR 490,000-500,000/ $\mathrm{kg}$ (Wahyudin et al., 2017). In order to fulfill the demand, spiny lobster was still caught in its natural habitat. As a consequent, The Ministry of Marine and Fisheries published a ministry regulation known as "Peraturan Menteri Kelautan dan Perikanan Republik Indonesia Nomor.1/ PERMEN-KP/2015" about the restriction of lobster (Panulirus spp.), crabs (Scylla spp.), and swimming crab (Portunus pelagicus spp.) captured which potentially reduce lobster population in Indonesia. It became a serious concern for aquaculturist to increase the spiny lobster production.

The common way to rear spiny lobster is in a floating cage, however, it is frequently constrained by several things, such as fluctuation of water quality, a high labor of controlling, ensuring the feed is efficiently eaten, controlling the cannibalism, and still lacking scientific data about optimum stock density. Most of the fish farmer uses extremely high stocking density and it leads to low growth rate or worst it causes mortality so that the production will be low (Wahyudin et al., 2017). It needs a process to switch from floating cage to controlled tanks that is why spiny lobster rearing in controlled tanks has already started in many countries, such as Vietnam and Australia and the result was much better. The transition of rearing technique from floating cage to controlled tanks also generates various innovations and research developments, such as shelter application adjusted with the stocking density of the experimental spiny lobster, individual compartment application, recirculation system which proven to reduce stress level, and mortality caused by cannibalism (Adiyana $e t$ al., 2014; Pratiwi et al., 2016; Djai et al., 2017; Supriyono et al., 2017).

The other effort to increase the productivity of spiny lobster is using high stock density to grow-out phase. High stocking density in spiny lobster rearing is done by using high stocking density along with intensive technique, such as optimum feeding and maintaining water quality in supportive condition. Rearing activity of spiny lobster was conducted when the spiny lobster has reached about $100 \mathrm{~g}$ until the harvest size about 150 g. Spiny lobster rearing in floating cage commonly used a stock density of 100 individuals $/ \mathrm{m}^{2}$, and the survival rate was ranged from $60-75 \%$ (Wahyudin et al., 2017). The study about high stocking density in controlled tanks has already done by Sakthivel et al. (2014) used spiny lobster size in 70-80 g and stocking density of 25 individuals $/ \mathrm{m}^{2}$ with the result of survival rate reached $80 \%$.

Rearing activity of spiny lobster with high stocking density is an important issue to be observed because it is a limiting factor which potentially decreases the production. A high stocking density of rearing will result in a limited area and creates competition in feed consumption because lobster lives on the bottom of rearing media (FAO, 2016). A high stocking density of spiny lobster rearing also faces with cannibalism of the lobster, especially when the lobster is having molting process. Moreover, stress factor also deserves serious attention because it potentially leads to lower growth rate and survival rate (Adiyana et al., 2014; Supriyono et al., 2017). Therefore, various parameter measurement (water quality, physiological response, and production performance) is mandatory to evaluate high stocking density determination in spiny lobster rearing.

Water quality test was conducted by measuring various water quality parameters, such as salinity, water temperature, $\mathrm{pH}$, and total ammonia nitrogen. A production performance was calculated through survival rate, weight and total length, and feed conversion ratio. While the physiological response was measured qualitatively through behavior observation and quantitatively through blood cell observation, blood $\mathrm{pH}$, oxygen consumption, hormone, and ion. This study aimed to determine optimum high stocking density in spiny lobster rearing to increase productivity.

\section{MATERIALS AND METHODS}

\section{Experiment period}

This study was conducted in February until March 2017 in Marine Laboratory, Bogor Agricultural University, Ancol, North Jakarta. Physiological response analysis was observed in Physiology Laboratory, Faculty of Veterinary, Bogor Agricultural University. Water quality test was done in Environment Laboratory, Aquaculture Department, Faculty of Fisheries and Marine Science, Bogor Agricultural University. 


\section{Experimental design}

The experimental design was complete randomized design with three treatments and two replications. The treatment was treatment modification according to Balkhair et al. (2012), Sakthivel et al. (2014), and Lee et al. (2015) with stocking density showed in Table 1.

Table 1. The high stocking density treatments on spiny lobster (Panulirus sp.) rearing in controlled tanks

\begin{tabular}{cc}
\hline Treatment & \multicolumn{1}{c}{ Note } \\
\hline $\mathrm{KT}_{10}$ & Stocking density of 10 individuals $/ \mathrm{m}^{3}$ \\
$\mathrm{KT}_{18}$ & Stocking density of 18 individuals $/ \mathrm{m}^{3}$ \\
$\mathrm{KT}_{26}$ & Stocking density of 26 individuals $/ \mathrm{m}^{3}$ \\
\hline
\end{tabular}

\section{Experiment procedure}

The experimental spiny lobster (Panulirus sp.) average weight and length at the beginning of the study was $130.39 \pm 0.32 \mathrm{~g}$ and $140.70 \pm$ $0.06 \mathrm{~mm}$, respectively. Sardinella sp. was used as feed to the spiny lobster. The experimental spiny lobster was adapted in two tanks size in $4 \times 1 \times 1.5 \mathrm{~m}^{3}$ using recirculation system with 500 $\mathrm{g}$ of sponge filter and $1.5 \mathrm{~kg}$ of bio-ball. The recirculation system was equipped with 1 unit of a protein skimmer. The adaptation period was performed for 14 days until the spiny lobster became active and had a good appetite. The feed which given to the spiny lobster was as many of $3 \%$ of total weight and the feeding frequency was once at 5 p.m. (Balkhair et al., 2012). The tanks used in this study was six tanks of fiber tanks size in $1.2 \times 0.95 \times 1 \mathrm{~m}^{3}$ filled with $800 \mathrm{~L}$ of seawater. The fiber tanks were cleaned, then a net was placed on every side of the tanks. Several pipes size $10 \mathrm{~cm}$ in diameter and $25 \mathrm{~cm}$ in length were put inside the tanks as shelter as many of 5:4 with the lobster population (Djai et al., 2017). The aeration system used microbubble system (Endo et al., 2008). The grow-out rearing activity of spiny lobster was conducted after the adaptation was finished. The feeding method adapted the similar method to the rearing adaptation.

\section{Experimental parameterand statisticalanalysis}

The experimental parameters in this study were water quality test, physiological response test, and production performance test. The water quality test consisted of dissolved oxygen, salinity, water temperature, and $\mathrm{pH}$ was done every day during the experiment, while the total ammonia nitrogen (TAN) was measured every 10 days referred to APHA method (2012). The physiological response parameters were total haemocyte count (THC) referred to Johansson et al. (2000), haemolymph glucose referred to Li et al. (2008), and behavior observation along with molting frequency referred to Kibria (1993). The physiological response measurement (THC and haemolymph glucose) was measured at the beginning of the experiment, day 1 , day 5 , day 10 , and every next 10 days. The production performance parameters consisted of weight growth and total length, specific growth rate, feed conversion rate, and survival rate referred to Solanki et al. (2012). All the data were statistically analyzed using complete randomized design and F-test in confidence interval 95\% with SPSS 16.0 and Microsoft Excel 2010. If the result was significantly different, posthoc test would be conducted.

\section{RESULTS AND DISCUSSION}

\section{Result \\ Water quality}

The water quality parameter which measured during this study consisted of water temperature, salinity, $\mathrm{pH}$, dissolved oxygen, and total ammonia nitrogen (TAN). The results were shown below in Table 2.

\section{Physiological response}

The total haemocyte count of spiny lobster

Table 2 . The water quality during the spiny lobster rearing

\begin{tabular}{|c|c|c|c|c|}
\hline \multirow{2}{*}{$\begin{array}{c}\text { Water quality } \\
\text { parameter }\end{array}$} & \multicolumn{3}{|c|}{ Treatment $^{*}$} & \multirow{2}{*}{ Optimum range } \\
\hline & $\mathrm{KT}_{10}$ & $\mathrm{KT}_{18}$ & $\mathrm{KT}_{26}$ & \\
\hline Temperature $\left({ }^{\circ} \mathrm{C}\right)$ & $26.75-28.44$ & $26.56-28.41$ & $26.75-28.65$ & $22-31^{\circ} \mathrm{C}$ (Jones, 2009) \\
\hline Salinity $(\mathrm{g} / \mathrm{L})$ & $29.8-33.6$ & $29.7-33.6$ & $29.8-33.6$ & 25-35 g/L (Vidya \& Joseph, 2012) \\
\hline $\mathrm{pH}$ & $7.5-8.1$ & $7.5-8.2$ & $7.5-8.5$ & 7,8-8,2 (Mojjada et al., 2012) \\
\hline $\mathrm{DO}(\mathrm{mg} / \mathrm{L})$ & $6.36-6.58$ & $6.15-6.51$ & $6.28-6.58$ & $>5$ mg/L (Rathinam et al., 2014) \\
\hline TAN (mg/L) & $0.11-0.32$ & $0.16-0.34$ & $0.11-0.27$ & $<0,5 \mathrm{mg} / \mathrm{L}$ (Verghese et al., 2007) \\
\hline
\end{tabular}

"Note: Stocking density treatment $10 \mathrm{ind} / \mathrm{m}^{3}\left(\mathrm{KT}_{10}\right) ; 18 \mathrm{ind} / \mathrm{m}^{3}\left(\mathrm{KT}_{18}\right)$; and $26 \mathrm{ind} / \mathrm{m}^{3}\left(\mathrm{KT}_{26}\right)$ 
overall experienced fluctuation. The THC concentration on day- 0 and day- 1 was not significantly different between treatments. The THC ranged from $2.45-2.85 \times 10^{6} \mathrm{cell} / \mathrm{mL}$ (Figure $1)$.

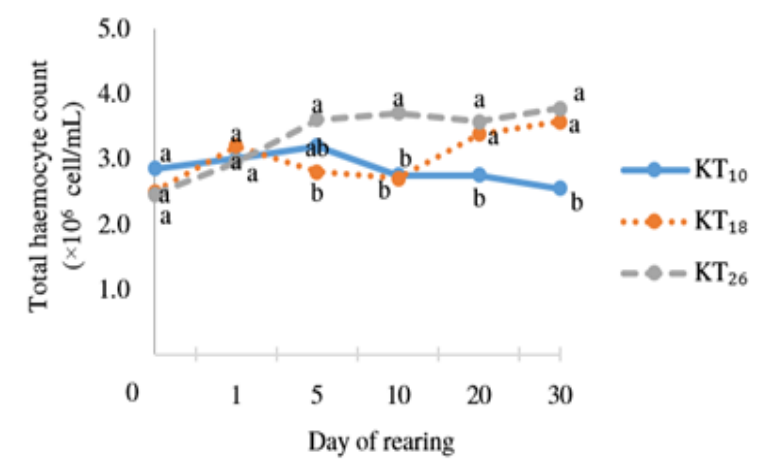

Figure 1. The mortality of tiger shrimp Penaeus monodon in challenge test of WSSV used mangrove extract of S. alba and B.gymnorrhiza. The figures on the same vertical line followed the same superscript showed that the results did not differ significantly $(\mathrm{P}>0.05)$.

On the next measurement, the THC parameter in the $\mathrm{KT}_{10}$ treatment tended to be more stable than the $\mathrm{KT}_{18}$ and $\mathrm{KT}_{26}$ treatment which tended to increase, so that it showed a significant difference on posthoc test. The THC concentration in $\mathrm{KT}_{10}$ treatment at the end of the study was $2.55 \times 10^{6}$ cell $/ \mathrm{mL}$, while the $\mathrm{KT}_{18}$ and $\mathrm{KT}_{26}$ were $3.57 \times 10^{6}$ cell $/ \mathrm{mL}$ and $3.77 \times 10^{6}$ cell $/ \mathrm{mL}$, respectively.

The haemolymph glucose in all treatments showed no significant difference between treatments. The concentration of haemolymph glucose ranged from $24.67-29.74 \mathrm{mg} / \mathrm{dL}$. The highest haemolymph glucose was in stocking density of $26 \mathrm{ind} / \mathrm{m}^{3}\left(\mathrm{KT}_{26}\right)$ as many as $29.74 \pm$ $4.39 \mathrm{mg} / \mathrm{dL}$. Nevertheless, the Duncan posthoc test showed no significant difference between treatments $(\mathrm{P}>0.05)$. The haemolymph glucose during the experiment showed in Figure 2.

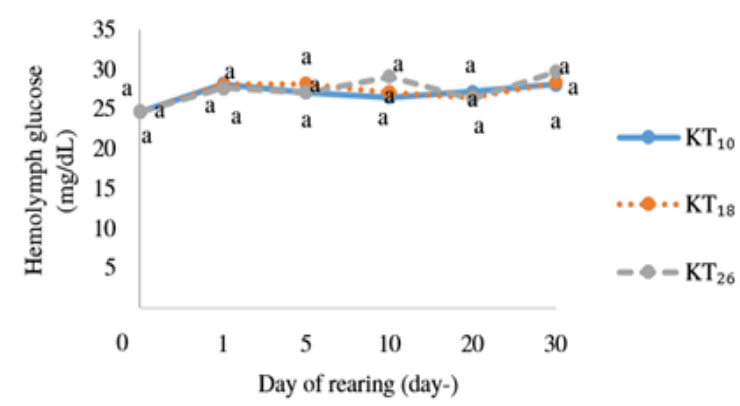

Figure 2. The haemolymph glucose of spiny lobster (Panulirus sp.) during the study with stocking density treatment $10 \mathrm{ind} / \mathrm{m}^{3}\left(\mathrm{KT}_{10}\right) ; 18 \mathrm{ind} / \mathrm{m}^{3}\left(\mathrm{KT}_{18}\right)$, and 26 $\mathrm{ind} / \mathrm{m}^{3}\left(\mathrm{KT}_{26}\right)$. The same superscript on the graphic indicates significant difference $(\mathrm{P}<0.05)$.
The behavior of the spiny lobster during the study was likely to stay still on the bottom of the tanks, but it moved rapidly backward by moving its body and swimming legs if it felt disturbed. The spiny lobster also could move passively using its walking legs. The net on the side of tanks was used as spaces for the spiny lobster to move around. The spiny lobster usually hangs on the net, especially when the afternoon feeding time was about to come.

The spiny lobster has an antenna as food detector. When the food came, the spiny lobster will quickly detect it with its antenna and grab it with its walking legs. The spiny lobster tends to fight over the food each other, so the pipe will function as shelter to protect them while eating. The antenna also functioned as unfamiliar objects detector which considered interfere them. During the study, the spiny lobsters were gather each other, however, sometimes they prefer to stay solitary, especially when they were eating or molting. The spiny lobster is active both in the daytime and nighttime. During the study, the spiny lobster seemed to be reactive to light and it would walk on the net to the water surface, however, when it detected something threaten, it would rapidly move into the shelter.

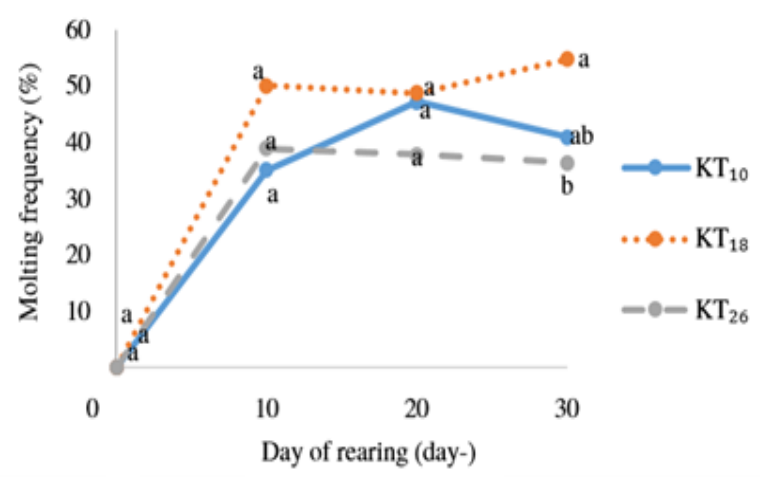

Figure 3. The molting frequency of spiny lobster (Panulirus sp.) during the study with stocking density treatment $10 \mathrm{ind} / \mathrm{m}^{3}\left(\mathrm{KT}_{10}\right) ; 18 \mathrm{ind} / \mathrm{m}^{3}\left(\mathrm{KT}_{18}\right)$, and 26 $\mathrm{ind} / \mathrm{m}^{3}\left(\mathrm{KT}_{26}\right)$. Different superscript on the graphic indicates significant difference $(\mathrm{P}<0.05)$.

The molting process of spiny lobster occurred in each treatment. The molting frequency of spiny lobster was different at each observation time and it ranged from 35-50\% during the study. The stocking density treatment $18 \mathrm{ind} / \mathrm{m}^{3}\left(\mathrm{KT}_{18}\right)$ showed higher molting frequency with the average molting frequency $51.1 \pm 3.2 \%$ during the study. The molting frequency of spiny lobster during the study was showed in Figure 3.

The molting process occurred quite fast, the carapace will be opened from the bottom side and the lobster will push its body using walking 
Table 3. The production performance of spiny lobster during the rearing period

\begin{tabular}{cccccc}
\hline & \multicolumn{5}{c}{ Production performance of spiny lobster } \\
\cline { 2 - 6 } Treatment* & $\begin{array}{c}\text { Final average } \\
\text { weight }(\mathrm{g})\end{array}$ & $\begin{array}{c}\text { Final average total } \\
\text { length }(\mathrm{mm})\end{array}$ & SGR $(\%)^{*}$ & FCR $^{*}$ & SR $(\%)^{*}$ \\
\hline $\mathrm{KT}_{10}$ & $145.98 \pm 1.36^{\mathrm{a}}$ & $142.82 \pm 0.19^{\mathrm{a}}$ & $0.38 \pm 0.0^{\mathrm{a}}$ & $7.63 \pm 0.06^{\mathrm{a}}$ & $85.0 \pm 7.07^{\mathrm{a}}$ \\
$\mathrm{KT}_{18}$ & $145.06 \pm 0.42^{\mathrm{a}}$ & $142.77 \pm 0.19^{\mathrm{a}}$ & $0.35 \pm 0.0^{\mathrm{a}}$ & $7.87 \pm 0.31^{\mathrm{a}}$ & $86.11 \pm 3.92^{\mathrm{a}}$ \\
$\mathrm{KT}_{26}$ & $139.80 \pm 0.33^{\mathrm{b}}$ & $142.04 \pm 1.35^{\mathrm{b}}$ & $0.22 \pm 0.0^{\mathrm{b}}$ & $12.57 \pm 0.04^{\mathrm{b}}$ & $84.61 \pm 0.0^{\mathrm{a}}$ \\
\hline
\end{tabular}

*Note: Stocking density treatment $10 \mathrm{ind} / \mathrm{m}^{3}\left(\mathrm{KT}_{10}\right) ; 18 \mathrm{ind} / \mathrm{m}^{3}\left(\mathrm{KT}_{18}\right)$; and $26 \mathrm{ind} / \mathrm{m}^{3}\left(\mathrm{KT}_{26}\right)$. SGR = specific weight growth rate; $\mathrm{FCR}=$ feed conversion rate; $\mathrm{SR}=$ survival rate. Different superscript letters in the same colom indicated significant difference $(\mathrm{P}<0.05)$.

legs. The molting process usually occurs inside a shelter to avoid cannibalism because a lobster tends to become weak caused by lack of energy for molting and the newborn carapace is still fragile.

\section{Production performance}

The production performances measured in this study were final average weight, final average total length, specific growth rate (SGR), feed conversion rate (FCR), and survival rate. The production performance results were shown in Table 3.

The production performance result showed that the highest result was showed by $\mathrm{KT}_{10}$ treatment, but it was not significantly different towards $\mathrm{KT}_{18}$ $(\mathrm{P}>0.05)$. Both $\mathrm{KT}_{10}$ and $\mathrm{KT}_{18}$ treatments were significantly different towards $\mathrm{KT}_{26}$ treatment $(\mathrm{P}<0.05)$. It was also directly proportional to the specific weight growth and FCR. The highest SR was achieved in $\mathrm{KT}_{18}$ treatment, but it was not significantly differencing with $\mathrm{KT}_{10}$ and $\mathrm{KT}_{26}$ treatments $(\mathrm{P}>0.05)$.

\section{Discussion}

Similar to other common aquaculture activity, the water quality becomes an important aspect to be considered. If the aquatic environment is an optimum range so that the aquatic biota will be well-developed. The water temperature ranged from $26.56-28.65^{\circ} \mathrm{C}$. The salinity in the rearing media ranged from 29.7-33.6 g/L. The $\mathrm{pH}$ level ranged from 7.52-8.23. The dissolved oxygen also relatively stable which ranged from 6.15-6.58 $\mathrm{mg} / \mathrm{L}$. The total ammonia nitrogen ranged from $0.11-0.34 \mathrm{mg} / \mathrm{L}$. Because of the recirculation system, the water quality in all treatments were relatively similar to each other. Even though the stocking density was different, it wasn't significantly difference between treatments. Overall, all the water quality parameter was still in the optimum range for lobster rearing (Table 2).
The physiological response of spiny lobster has to be considered in order to achieve the production goals. The observation of the physiological responses was conducted through the calculation of haemocyte, haemolymph, and lobster behavior. The haemocyte in crustacean indicates the health level (Jensen et al., 2013). In this study, total haemocyte count was calculated in each period and it had fluctuation and experienced an increase at the beginning of the study. The increasing of total haemocyte count indicated a stress condition on spiny lobster caused by the treatment. The stress condition occurred when the stocking density was excessive. When the spiny lobster was exposed by stress condition, total haemocyte count would be increased and induce the immune system and as a disease barrier (Johansson, 2000).

Leland et al. (2013) stated that stress could cause the trouble on homeostasis until it got beyond the normal condition. Haemocyte is a defense system for the crustaceans which functioned as unfamiliar particle detector and disease agent, encapsulation, phagocytosis, and toxic degradation (Johansson et al., 2000). This important role of haemocyte also become a stress indicator. The normal THC on American lobster Homarus americanus ranged from 1.3-2.1 $\left(\times 10^{6}\right.$ cell $/ \mathrm{mL}$ ) (Basti et al., 2010). While the THC on Carribean spiny lobster Panulirus argus ranged from 2.3-6.5 $\left(\times 10^{6}\right.$ cell $\left./ \mathrm{mL}\right)$ in salinity level of 25-35 g/L (Verghese et al., 2007). According to those facts, the THC of spiny lobster during the study was in a tolerance range and it indicated that the experimental lobsters were healthy. Nevertheless, the higher value of THC in higher stocking density indicated that the lobster in higher stocking density was experiencing stress condition caused by treatment.

The haemolymph glucose of the experimental lobster during rearing period fluctuated and increased, even though it didn't a significant difference between treatments. The increasing of blood glucose was caused by stress condition. 
Hastuti et al. (2003) stated that the blood glucose was directly affected by stress condition. Hyperglycemia is an initial indicator of stress because the glucose level is sensitive to stress hormone. The higher blood glucose indicates an increase in stress level caused by the stressor. The glucose concentration is directly affected by insulin hormone, while in crustaceans, the exact glucose mechanism in haemolymph has not been observed yet. The crustaceans have no pancreatic gland as insulin hormone producer. The glucose in haemolymph is assumed to be regulated by an insulin-like hormone produced by hepatopancreatic, called insulin-like growth factors (IGF-I). The hormone mechanism is influential to the stress endurance caused by environmental changes, such as salinity and $\mathrm{pH}$, so that it regulates glucose supply to become energy source during stress condition and regulates osmoregulation in crustaceans (Gutierez et al., 2007; Wang et al., 2017).

Ramachandra and Kishori (2017) stated that glucose in haemolymph was regulated by neuropeptide crustacean hyperglycemic hormone $(\mathrm{CHH})$ which produced by sinus gland in the crustacean. There is also neuropeptide moltinhibiting hormone (MIH) and mandibular-organ inhibiting hormone $(\mathrm{MOIH})$ which secreted from sinus gland. Those hormones not only regulate glucose balance in haemolymph, but also regulate molting, osmoregulation, and reproduction. In crustacean, when the eyestalk ablation was conducted, that hormone will be secreted more than usual to induce growth through molting and energy saving. It explained that in crustacean, although there is no insulin hormone to regulate the glucose in haemolypmh, there is some hormone which work the same mechanism as insulin in the vertebrates.

Lobster is a grouping animal living under the reef on the sandy environment. They live together in a group in order to prevent predator (Wahyudin et al., 2017). The stocking density treatment in this study showed its correlation towards behavior which not significantly different. Nevertheless, the molting frequency during the study showed some differences. The molting frequency in $\mathrm{KT}_{18}$ treatment showed higher result compared with the other treatments $(54.79 \pm 2.06 \%)$. Lobsters experienced molting in order to gain growth. Molting process also functioned to repair some damaged part, such as leg or fracture antenna. Lobster is an exoskeleton animal, so they need to change their skin in order to growth (Supriyono et al., 2017). According to its grouping mechanism, it showed that even though the stocking density is high, lobster constantly experiencing molting. It was caused by besides feed controlling and water quality maintenance, providing shelter was one of the reasons to protect the lobster while molting without experiencing threaten (Djai et al., 2017). The aquaculture concept is connected to each other with stocking density, growth, survival rate, and water quality. The optimum stocking density allows the biota to growth properly so that the aquaculture activity will be profitable. The stocking density will affect the growth rate because the lobsters will fight over spaces and food. When the higher stocking density is not followed by enough spaces and advance feeding, the growth will be decreasing (Djai et al., 2017; Supriyono et al., 2017).

The growth performance of spiny lobster during the experiment was related to the physiological responses. Overall, physiological responses showed stress indicator on high stocking density. The molting frequency during the experiment on higher stocking density also tended to decrease compared with the lower stocking density. Stress condition on spiny lobster caused the production performance stranded (Adiyana et al., 2014; Djai et al., 2017).

Growth is dimension changes, include weight and length in a certain period of time and survival rate is a final percentage of the living organism compared to initial stocking density during a certain period of rearing. Growth is affected by two major factors: (1) internal factor related to genetically characters and physiological condition, and (2) external factors related to the environment, such as water chemistry, temperature, metabolism rate, oxygen supply, and feed (Solanki et al., 2012).

The result of the production performance showed that the higher stocking density, the production performance would be decreased (Table 3). The growth of spiny lobster on high stocking density was decreased and it caused the specific growth decreased and the feed conversion ratio increased. The high feed conversion ratio was caused by trash fish which were given to the lobsters. In addition, the nutrition adequacy in trash fish has not fulfilled the nutrient requirement on the spiny lobster. Nevertheless, the survival rate of spiny lobster during the experiment was quite high ranged from $84.61-86.11 \%$. The result of survival rate in this experiment was higher than the experiment by Sakthivel et al. (2014) which only reached $80 \%$. The survival rate is an important factor because the final population will 
determine the level of success of an aquaculture activity. The $\mathrm{KT}_{18}$ showed the highest survival rate during the experiment. It described a higher production performance compared with other treatments, supported by growth treatment and initial stocking density. High survival rate on spiny lobster rearing is an important factor in increasing production (FAO, 2016).

\section{CONCLUSION}

The grow-out activity of spiny lobster was able to be conducted in stocking density if $18 \mathrm{ind} / \mathrm{m}^{3}$. It is supported by several physiological response and production performance parameters which generally no significant difference with a stocking density of $10 \mathrm{ind} / \mathrm{m}^{3}$.

\section{REFERENCES}

Adiyana K, Supriyono E, Junior MZ, Thesiana L. 2014. Application of various shelter on stress response and survival rate of spiny lobster Panulirus homarus nursery. Jurnal Kelautan Nasional 9: 1-9.

[APHA] American Public Health Association. 2012. Standard methods for the examination of water and waste water. 22th edition. Washington DC (US): APHA Pr .

Balkhair M, Al-Mashiki A, Chesalin M. 2012. Experimental rearing of spiny lobster Panulirus homarus (Palinuridae) in landbased tanks at Mirbat Station (Sultanate of Oman) in 2009-2010. Agricultural and Marine Sciences 17: 33-43.

Basti D, Bricknell I, Hoyt K, Chang ES, Halteman W, Bouchard D. 2010. Factors affecting postcapture survivability of lobster Homarus americanus. Diseases of Aquatic Organisms 90: 153-166.

Djai S, Supriyono E, Nirmala K, Adiyana K. 2017. Total hemocyte count and hemolymph glucose concenration response of spiny lobster Panulirus homarus on ratio of shelter. Jurnal Ilmu dan Teknologi Kelautan Tropis 9: 125133.

Endo A, Sarawut S, Hisatsune N, Ichiro T, Takaaki I, Daigo H, Hiroaki T. 2008. DOincreasing effects of a microscopic bubble generating system in a fish farm. Marine Pollution Bulletin 57: 78-85.

[FAO] Food and Agriculture Organization. 2016. Cultured aquatic species information program: Panulirus homarus (Linnaeus, 1878). Fisheries and Aquaculture Department United Nations. http://www.fao.org/fishery/culturedspecies/ Panulirus_homarus/en [4 November 2016].

Gutierez A, Nieto J, Pozo F, Stern S, Schoofs L. 2007. Effect of insulin/IGF-I like peptides on glucose metabolism in the white shrimp Penaeus vannamei. General and Comparative Endocrinology 153: 170-175.

Hastuti S, SupriyonoE, MokogintaI, Subandiyono. 2003. Blood glukose response of giant gouramy Osphronemus gouramy Lac. to the stress of environmental temperature changes. Jurnal Akuakultur Indonesia 2: 73-77.

Jensen MA,Carter CG, Adams LR, Fitzgibbon QP. 2013. Growth and biochemistry of the spiny lobster Sagmariasus verreauxi cultured at low and high density from hatch to puerulus. Aquaculture 379: 162-170.

Johansson MW, Keyser P, Sritunyalucksana K, Soderhall K. 2000. Crustacean haemocytes and haematopoiesis. Aquaculture 191: 45-52.

Jones CM. 2009. Temperature and salinity tolerances of the tropical spiny lobster, Panulirus ornatus. Journal of the World Aquaculture Society 40: 744-752.

Kibria G. 1993. Studies on molting, molting frequency and growth of shrimp Penaeus monodon fed on natural and compounded diets. Asian Fisheries Science 6: 203-211.

Lee S, Harstein ND, Jeffs A. 2015. Characterising the fate of nitrogenous waste from the seacage aquaculture of spiny lobsters using numerical modelling. Environment Science Pollution Research 22: 9356-9369.

Leland JC, Butcher PA, Broadhurst MK, Paterson BD, Mayer DG. 2013. Damage and physiological stress to juvenile eastern rock lobster Sagmariasus verreauxi discarded after trapping and hand collection. Fisheries Research 137: 63-70.

Li C, Shields JD, Ratzlaff RE, Butler MJ. 2008. Pathology and hematology of the Caribbean spiny lobster experimentally infected with Panulirus argus virus 1 (PaV1). Virus Research 132: 104-113.

Mojjada SK, Joseph I, Koya MK, Sreenath KR, Dash G, Sen S, Fofandi D, Anbarasu M, Bhint HM, Pradeep S, Shiju P, Rao GS. 2012. Capture based aquaculture of mud spiny lobster Panulirus polyphagus (Herbst 1793) in open sea floating cages of Veraval, Northwest coast of India. Indian Journal of Fisheries 59: 29-34.

Pratiwi R, Supriyono E, Widanarni. 2016. Total hemocytes, glucose hemolymph, and production performance of spiny lobster 
Panulirus homarus cultured in the individual compartments system. Jurnal Ilmu dan Teknologi Kelautan Tropis 8: 321-333.

Ramachandra RP, Kishori B. 2017. Crustacean endocrinology: Intriguing towards quality protein production. Journal of Endocrinology and Thyroid Research 1: 1-5.

Rathinam MM, Kizhakudan JK, Vijayagopal P, Jayakansar V, Leslie VA, Sundari R. 2014. Effect of dietary protein levels in the formulated diets on growth and survival of juvenile spiny lobster Panulirus homarus (Linnaeus). Indian Journal Fisheries 61: 67-72.

Sakthivel M, Jawahar G, Palanikumar M. 2014. Effects of stocking density on food utilization in the spiny lobster Panulirus homarus. International Conference on Multidisciplinary Research and Practice 1: 478-481.

Solanki Y, Jetani KL, Khan SI, Kotiya AS, Makawana NP, Rather MA. 2012. Effect of stocking density on growth and survival rate of spiny lobster Panulirus polyphagus in cage culture system. International Journal of Aquatic Science 3: 42-49.
Supriyono E, Prihardianto RW, Nirmala K. 2017. The stress and growth responses of spiny lobster Panulirus homarus reared in recirculation system equipped by $\mathrm{PVC}$ shelter. AACL Bioflux 10: 147-155.

Verghese B, Radhakrishnan EV, Padhi A. 2007. Effect of environmental parameters on immune response of the Indian spiny lobster Panulirus homarus (Linnaeus, 1758). Fish and Shellfish Immunology 23: 928-936.

Vidya K, Joseph S. 2012. Effect of salinity on growth and survival of juvenile Indian spiny lobster Panulirus homarus (Linnaeus). Indian Journal Fisheries 59: 113-188.

Wahyudin A, Hakim AA, Qonita Y, Boer M, Farajallah A, Mashar A, Wardianto Y. 2017. Lobster diversity of Palabuhanratu Bay, South Java, Indonesia with new distribution record of Panulirus ornatus, $P$. polyphagus and Parribacus antarticus. AACL Bioflux 10: 308-327.

Wang X, Li E, Xu Z, Chen L. 2017. Molecular response of carbohydrate metabolism to dietary carbohydrate and acute low salinity stress in 